\title{
Analisis Efek Konsentrasi Ekstrak Etanol Daun Senggani (Melastoma malabathricum L.) Sebagai Antibakteri Staphylococcus aureus
}

\section{Analysis of the Effects of the Ethanol Extracts of Senggani (Melastoma malabathricum L.) Leaves as Staphylococcus aureus Antibacterial}

\author{
Nurhayat $^{1}$, Yuliar ${ }^{2}$, Mauritz Pandapotan Marpaung ${ }^{3 *}$ \\ 1,2,3 Program Studi S1 Farmasi, Fakultas Farmasi, Universitas Kader Bangsa, Palembang, \\ Indonesia \\ *Email Korespondensi: mauritzchem@gmail.com
}

\begin{abstract}
Abstrak
Latar belakang: Tanaman Senggani mempunyai banyak potensi sebagai pengobatan seperti antipiretik, analgesik, diuretik, dan antibakteri.

Tujuan:untuk menganalisis efek konsentrasi ekstrak etanol daun senggani sebagai antibakteri Staphylococcus aureus.

Metode: Daun senggani diekstraksi dengan perendaman dalam etanol 96\%. Diameter zona hambat bakteri diukur dengan menggunakan metode difusi agar melalui lima perlakuan yaitu kontrol positif (kloramfenikol), kontrol negatif (NaCMC), dan ekstrak daun senggani konsentrasi 20\%, 40\%, 60\%, dan $80 \%$.Data yang dihasilkan dianalisis dengan metode statistik Kruskal-Wallis dan uji lanjut post hoc Mann Whitney.

Hasil: Rata-rata diameter zona hambat pertumbuhan bakteri yang dihasilkan pada ekstrak $20 \%$

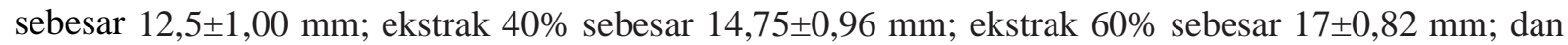
ekstrak $80 \%$ sebesar 19,5 $\pm 1,00 \mathrm{~mm}$.Hasil uji Kruskal-Wallis menunjukkan ada pengaruh antara ratarata diameter zona hambat pertumbuhan bakteri Staphylococcus aureus dengan kelompok larutan uji ( $<<0,000)$. Pada uji post hoc Mann Whitney terdapat perbedaan yang signifikan antar kelompok larutan uji $(\mathrm{p}<0,05)$.

Kesimpulan: semakin besar konsentrasi ekstrak daun senggani maka diameter zona hambat pada pertumbuhan bakteri Staphylococcus aureus semakin besar.
\end{abstract}

Kata kunci: Daun senggani, diameter zona hambat, Staphylococcus aureus.

\begin{abstract}
Background: Senggani plants have a lot of potential as a treatment such as antipyretics, analgesics, diuretics, and antibacterial.

Objective: to analyze the effect of the concentration of ethanol extract of senggani leaves as an antibacterial Staphylococcus aureus.

Method: Senggani leaves were extracted by soaking in $96 \%$ ethanol. Bacterial inhibition zone diameters were measured using a diffusion method through five treatments namely positive control (chloramphenicol), negative control (NaCMC), and senggani leaf extract concentrations of $20 \%$, $40 \%, 60 \%$, and $80 \%$. The resulting data were analyzed by the Kruskal-Wallis statistical method and Mann Whitney's post hoc test.

Result: The average diameter of the zone of inhibition of bacterial growth produced in extracts of $20 \%$ was $12.5 \pm 1,00 \mathrm{~mm}$; extract $40 \%$ of $14.75 \pm 0.96 \mathrm{~mm}$; extract $60 \%$ by $17 \pm 0.82 \mathrm{~mm}$, and extract $80 \%$ of $19.5 \pm 1.00 \mathrm{~mm}$. Kruskal-Wallis test results showed that there was an influence between the average diameter of the zone of growth inhibition of Staphylococcus aureus bacteria and the test solution group $(p<0.000)$. In Whitney's post hoc test there were significant differences between groups of test solutions $(p<0.05)$
\end{abstract}


Conclusion: the greater the concentration of senggani leaf extract, the inhibitory zone diameter in the growth of the Staphylococcus aureus bacteria is greater.

Keywords: Senggani leaf, inhibitory zone diameter, Staphylococcus aureus.

\section{PENDAHULUAN}

Indonesia merupakan negara tropis terbesar ketujuh dunia yang memiliki kekayaan flora dengan 20.000 jenis flora dimana 8000 spesiesmerupakan tanaman khas dari Indonesia. Hal ini dipengaruhi oleh letak geografis Indonesia sebagai negara kepulauan yang dikelilingi oleh benua Asia dan benua Australia. ${ }^{1}$ Dari jumlah jenis tumbuhan tersebut, sekitar $50 \%$ telah diketahui mempunyai khasiat sebagai obat, dan 200 jenis diantaranya telah dimanfaatkan sebagai bahan baku obat tradisional. ${ }^{2}$

Tumbuhan obat merupakan salah satu bahan alam alternatif yang digunakan untuk mencegah dan mengobati berbagai penyakit. Salah satu tumbuhan yang dimanfaatkan sebagai obat oleh masyarakat adalah tumbuhan senggani(Melastoma malabathricumL.) dari suku Melastomaceae.Tanaman ini berkhasiat sebagai penurun demam (antipiretik), pereda nyeri (analgesik), peluruh air seni (diuretik), mengobati keputihan (leukorea), dan obat berbagai jenis luka sayat. ${ }^{3}$

Dari beberapa khasiat yang terdapat pada tumbuhan tersebut disebabkan adanya senyawa aktif yang terkandung di dalamnya. Hasil skrining fitokimia menunjukkan ekstrak etanol daun senggani mengandung senyawa tannin, flavonoid, saponin dan polifenol. ${ }^{4}$ Peranan senyawa aktif tersebut memiliki khasiat dalam pengobatan sebagai antikanker, antioksidan, dan antibakteri.

Dari penelitian sebelumnya, ekstrak daun senggani dalam fraksi etil asetat dan metanol mampu menghambat pertumbuhan Escherichia coli sebagai bakteri Gram-negatif dengan konsentrasi hambat minimum masing-masing $250 \mu \mathrm{g} / \mathrm{ml}$ dan $1000 \mu \mathrm{g} / \mathrm{ml}{ }^{5}$ Daun senggani juga dapat menghambat bakteri Streptococcus mutans sebagai bakteri Gram-positifdengan konsentrasi 50-100\% memberikan daya hambat dengan kategori sedang dan konsentrasi 6,25$25 \%$ memberikan daya hambat dengan kategori lemah. ${ }^{6}$ Ekstrak ini juga dapat menghambat bakteri Staphylococcus aureusdanEscherichia coli dengan konsentrasi minimum masingmasing sebesar $2 \%$ dan $3 \%$. $^{4}$

Berdasarkan penelitian tersebut, konsentrasi ekstrak merupakan salah satu faktor terpenting dalam menghambat dan membunuh pertumbuhan suatu mikroba tanpa mengesampingkan faktor-faktor lain seperti jenis pelarut, metode ekstraksi yang digunakan, waktu ekstraksi, jenis bakteri uji, dan media uji yang digunakan. Hal ini disebabkan konsentrasi ekstrak menyatakan banyaknya senyawa aktifsebagai antimikroba yang tersari di dalam suatu ekstrak. Oleh sebab itu, penelitian ini bertujuan untuk menganalisis bagaimana efek atau pengaruh konsentrasi ekstrak daun senggani dalam menghambat bakteri Staphylococcus aureus.

Staphylococcus aureus merupakan bakteri gram positif yang bersifat patogen dan banyak ditemukan pada bagian tubuh manusia seperti kulit, saluran pernapasan, saluran pencernaan, saluran lendir pada mulut dan hidung. Penyakit yang sering diakibatkan oleh bakteri ini adalah infeksi pada kulit, infeksi pada tulang, paru-paru basa (pneumonia), radang otak dan radang pada sendi (arthritis). ${ }^{7}$ Dari beberapa penyakit yang ditimbulkan oleh bakteri tersebut, diperlukan antibiotik bahan alam seperti daun senggani. Dengan adanya beberapa kandungan senyawa metabolit sekunder dan penelitian terdahulu, secara prakilinis daun senggani dapat dijadikan sebagai bahan alam antibakteri.

Untuk menganalisis pengaruh atau efek konsentrasi esktrak daun senggani sebagai antibakteridilakukan uji statistika melalui uji Kruskal-Wallis. Ketika terdapat pengaruh konsentrasi ekstrak terhadap daya hambat bakteri dilakukan uji lanjut Mann-Whitney. Dari 
hasil analisis tersebut dapat diketahui konsentrasi ekstrak yang berpengaruh dalam menghambat pertumbuhan bakteri sehingga diperoleh keefektifan konsentrasi ekstrak daun senggani sebagai antibakteri.

\section{METODE}

\section{Waktu dan Tempat}

Penelitian ini dilakukan dengan metode eksperimen di Laboratorium Farmasi Universitas Sriwijaya untuk pembuatan ekstrak dan Balai Besar Laboratorium Kesehatan (BBLK) Palembang.untuk pengujian bakteripada bulan Maret 2019 sampai dengan Juni 2019.

\section{Alat dan Bahan}

Alat-alat yang digunakan adalah gelas ukur (pyrex), gelas kimia (pyrex), batang pengaduk, tabung reaksi (iwaki), destilasi vakum, cawan petri, vial (anugerah botol), pipet tetes (iwaki), penjepit kayu, jarum ose, pinset, timbangan analitik (Shimadzu), spatula, inkubator, autoklaf, rotary evaporator, jangka sorong (kenmaster), pipet mikro, lampu spiritus, dry heat oven, dan labu ukur (pyrex).

Bahan-bahan yang digunakan adalah nutrient agar (Himedia), kloramfenikol, aquadest, NaCMC (Natrium Carboxy Methyl Cellulose) 1\% (lansida), tissu, kertas saring (griya as syifa), kertas cakram (blank disc), kassa steril (one med), kapas lidi steril (one med), etanol p.a (Merck), $\mathrm{HCl}$, pereaksi Dragendorff, pereaksi Mayer, $\mathrm{FeCl}_{3}$, magnesium, asam klorida, dietil eter, asam asetat anhidrat, dan $\mathrm{H}_{2} \mathrm{SO}_{4}$.

Daun senggani diperoleh dari Desa Pangkalan Gelebek, Kabupaten Banyuasin, Sumatera Selatan. Sampel tersebut dideterminasi di Laboratorium Herbarium, Fakultas Biologi, Universitas Andalas, Padang.Untuk pengujian bakteri, Staphylococcus aureus diperoleh dari Balai Besar Laboratorium Kesehatan (BBLK) Palembang.

\section{Preparasi Sampel}

Sampel daun senggani segar dilakukan pencucian, perajangan, danpengeringan dibawah sinar matahari tidak langsung sampai kering. Lalu dihaluskan dan diayak untuk memperolehserbuk simplisia kering. Simplisia yang dihasilkan ditimbang bobotnya dan disimpan pada suhu kamar.

\section{Ekstraksi}

$500 \mathrm{~g}$ serbuk simplisia daun senggani diekstraksi dengan metode maserasi dalam pelarut etanol 96\%dengan pengadukan sesekali.Pergantian pelarut dilakukan setiap 3 hari sebanyak 3kali maserasi dan dilakukan penyaringan dengan kertas saring. Semua filtrat dikumpulkan dan diuapkan denganrotary evaporator pada suhu $60^{\circ} \mathrm{C}$ dan diuapkan dengan penangas airsampai diperoleh ekstrak kental. Lalu ditimbang dan dihitung persentase rendemen.

\section{Skrining Fitokimia}

Uji fitokimia dilakukan untuk menentukan komponen bioaktif yang terdapat pada ekstrak etanol daun senggani.Uji fitokimiayang dilakukan secara kualitatif terdiri dari uji alkaloid, flavonoid, tanin, saponin, polifenol dan steroid/triterpenoid.

\section{Uji alkaloid}

Ekstrak yang ditambahkan dengan $\mathrm{HCl} 2 \%$ diuji dengan pereaksi Dragendorff dan Mayer. Adanya alkaloid ditandai dengan endapan jingga pada pereaksi Dragendorff dan endapan putih pada pereaksi Mayer. 


\section{Uji saponin}

Ekstrak dilarutkan dalam air panas dan digojog sampai adanya busa. Adanya saponin apabila busa tidak hilang ketika ditambahkan $\mathrm{HCl} 1 \%$.

\section{Uji tanin}

Ekstrak dididihkan dengan $20 \mathrm{ml}$ air dan disaring. Adanya tanin memberikan warna larutan coklat hijau atau biru hitam ketika penambahan beberapa tetes $\mathrm{FeCl}_{3} 1 \%$.

\section{Uji flavonoid}

Ekstrak ditambah dengan sedikit serbuk Mg sampai tercampur. Kemudian ditambahkan $\mathrm{HCl}$ pekat dan menghasilkan larutan dengan warna jingga, merah, atau kuning menunjukkan adanya flavonoid.

\section{Uji steroid dan triterpenoid}

Ekstrak dilarutkan dalam dietil eter lalu diambil filtrat dan ditambahkan asam asetat anhidrat dan $\mathrm{H}_{2} \mathrm{SO}_{4}$ pekat. Adanya steroid memberikan warna hijau biru sedangkan adanya triterpenoid menunjukkan larutan berwarna merah-ungu.

\section{Uji Polifenol}

Ekstrak ditambahkan $10 \mathrm{ml}$ eter dan dipanaskan. Filtrat yang diteteskan dengan $\mathrm{FeCl}_{3}$ akan memberikan warna hijau, merah, ungu, biru tua, biru hitam atau hitam hijau menunjukkan adanya polifenol.

\section{Pembuatan Media NA(Nutrient Agar)}

3,7 gramNA dimasukkan kedalam Erlenmayer dan ditambah $100 \mathrm{ml}$ aquadest steril. Dipanaskan diatas kompor listrik sampai homogen.Kemudian ditutup kapas dan disterilkan dalam autoklaf dengan suhu $121^{\circ} \mathrm{C}$ selama 15 menit.

\section{Pembuatan Suspensi Bakteri}

Bakteri dibiakkan dengan cara diinkubasi dengan NAmiring selama 24 jam pada suhu $37^{\circ} \mathrm{C}$. Kemudiandiambilmenggunakan jarum ose dan disuspensikan ke dalam pelarut $\mathrm{NaCl}$ 0,9\% dalam kuvet. Lalu dikocok sampai homogen.

\section{Uji aktivitas antibakteri}

Uji aktivitas antibakteri dilakukan dengan menggunakan kertas cakram melalui metode difusi agar. Kertas cakram tersebut dicelupkan ke dalam ekstrak dengan konsentrasi $20 \%$, $40 \%, 60 \%$, dan $80 \%$. Kemudian diletakkan di atas media NA yang telah diinokulasi dengan bakteri uji dan diinkubasi selama 24 jam. Prosedur ini dilakukan pengulangan sebanyak 4 kali replikasi. Pengukuran diameter zona hambat di sekitar kertas cakram menggunakan jangka sorong yang dinyatakan dalam satuan milimeter $(\mathrm{mm})$.

\section{Analisis Data}

Data yang dihasilkan dianalisis menggunakan metode statistik dengan uji Kruskal-Wallis untuk mengetahui pengaruh konsentrasi ekstrak terhadap daya hambat pertumbuhan bakteri uji. Apabila terdapat perbedaan, maka dilakukan uji lanjut post-hoc Mann Whitney untuk mengetahui perbedaan yang signifikan setiap kelompok. 


\section{HASIL}

\section{Hasil determinasi tanaman}

Untuk menentukan spesifikasi tanaman yang diteliti dilakukan determinasi. Hasil determinasi dari tanaman senggani yang diteliti memiliki nama dengan spesies Melastoma malabathricum L.

\section{Hasil ekstraksi}

Bobot ekstrak kental yang diperoleh dari hasil ekstraksi 500g serbuk simplisia kering daun senggani dengan metode maserasi sebesar 61,28g. Dari hasil ekstraksi tersebut diperoleh persentase rendemen ekstrak sebesar $12,25 \%$.

\section{Hasil fitokimia}

Pada Tabel 1 menunjukkan hasil uji kualitatif metabolit sekunder pada ekstrak daun senggani melalui uji reaksi warna.Ekstrak daun senggani positif mengandung senyawa alkaloid, flavonoid, tanin, saponin, polifenol dan steroid sedangkan triterpenoid tidak terkandung di dalamnya.

\section{Tabel 1. Hasil Skrining Fitokimia Ekstrak Daun Senggani secara Kualitatif}

\begin{tabular}{|c|c|c|c|c|}
\hline Uji Fitokimia & Pereaksi & Kriteria Uji & Hasil Pengamatan & Keterangan \\
\hline \multirow{2}{*}{ Alkaloid } & Dragendorff & Endapan jingga & Endapan jingga & + \\
\hline & Wagner & Endapan putih & Endapan putih & + \\
\hline Flavonoid & $\mathrm{Mg}+\mathrm{HCl}$ & Warna jingga, merah atau kuning & Warna kuning & + \\
\hline Tanin & $\mathrm{FeCl}_{3} 1 \%$ & Warna coklat-hijau atau biru-hitam & Warna biru-hitam & + \\
\hline Saponin & $\mathrm{HCl} 1 \%$ & Busa yang stabil & Busa stabil & + \\
\hline Polifenol & $\mathrm{Eter}+\mathrm{FeCl}_{3}$ & $\begin{array}{l}\text { Warna hijau, merah, ungu, biru tua, biru hitam } \\
\text { atau hitam hijau }\end{array}$ & Warna hijau & + \\
\hline Steroid & Dietil eter + & Warna hijau-biru & & + \\
\hline Triterpenoid & $\begin{array}{l}\text { asam asetat } \\
\text { anhidrat dan } \\
\mathrm{H}_{2} \mathrm{SO}_{4} \text { pekat. }\end{array}$ & Warna merah-ungu & Warna hijau-biru & - \\
\hline
\end{tabular}

Keterangan:

+: Terkandung senyawa

- : Tidak terkandung senyawa

\section{Hasil uji aktivitas antibakteri}

Pengujian daya hambat ekstrak daun senggani terhadap pertumbuhan bakteri pada Gambar 1 dilakukan dengan metode difusi agar.Hasil pengujian daya hambat bakteri berupa pengukuran diameter zona hambat dengan menggunakan jangka sorong.

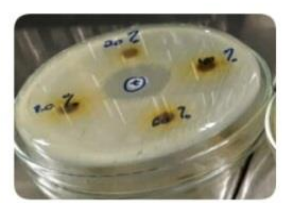

Percobaan 1

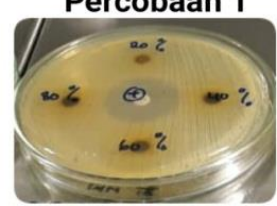

Percobaan 3

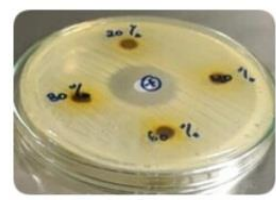

Percobaan 2

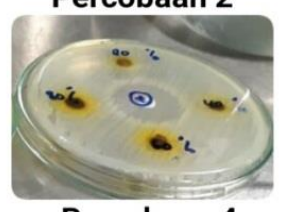

Percobaan 4

Gambar 1.Pengujian Aktivitas Antibakteri Ekstrak Daun Senggani dengan Empat Kali Replikasi. 
Setelah melakukan pengukuran, diperoleh nilai diameter hambat bakteri dan kategori zona hambat masing-masing sampel. Pada Tabel 2 menunjukkan rata-rata diameter hambat bakteri terendah terdapat pada konsentrasi ekstrak $20 \%$ dan tertinggi pada konsentrasi ekstrak $80 \%$. Seluruh konsentrasi ekstrak memiliki kategori zona hambat bakteri kuat sedangkan kloramfenikol sebagai kontrol positif memiliki kategori zona hambat sangat kuat.

Tabel 2. Hasil Pengukuran Diameter Zona Hambat Bakteri Staphylococcus aureus

\begin{tabular}{|c|c|c|c|c|c|c|}
\hline \multirow{2}{*}{ Sampel } & \multicolumn{4}{|c|}{ Diameter zona hambat (mm) } & \multirow{2}{*}{$\begin{array}{c}\text { Rata-rata }(\mathrm{mm}) \\
\qquad(\mathrm{x} \pm \mathrm{SD})\end{array}$} & \multirow{2}{*}{$\begin{array}{c}\text { Kategori } \\
\text { zona hambat }\end{array}$} \\
\hline & $\mathrm{R} 1$ & $\mathrm{R} 2$ & R3 & $\mathrm{R} 4$ & & \\
\hline Ekstrak $20 \%$ & 14 & 12 & 12 & 12 & $12,5 \pm 1,00$ & Kuat \\
\hline Ekstrak $40 \%$ & 16 & 14 & 14 & 15 & $14,75 \pm 0,96$ & Kuat \\
\hline Ekstrak $60 \%$ & 18 & 16 & 17 & 17 & $17 \pm 0,82$ & Kuat \\
\hline Ekstrak $80 \%$ & 20 & 18 & 20 & 20 & $19,5 \pm 1,00$ & Kuat \\
\hline Kontrol (+) & 27 & 25 & 30 & 27 & $27,25 \pm 2,06$ & Sangat kuat \\
\hline Kontrol (-) & 0 & 0 & 0 & 0 & 0 & Tidak ada \\
\hline
\end{tabular}

Keterangan:

Kontrol (+) : kloramfenikol

Kontrol (-) : NaCMC

R: Replikasi

Dari hasil data berupa diameter zona hambat ekstrak dianalisis secara statistika dengan menggunakan uji Kruskal-Wallis.Dari hasil uji tersebut menunjukkan ada pengaruh konsentrasi ekstrak daun senggani terhadap daya hambat pertumbuhan bakteri Staphylococcus aureus dengan nilai $p$ value melalui Asymp. Sig<0,05 (Tabel 3).

Tabel 3.Uji Kruskal-Wallis

\begin{tabular}{ll}
\hline & Diameter zona hambat S. Aureus \\
\hline Chi-square & 22.340 \\
Df & 5 \\
Asymp & .000 \\
.Sig & \\
\hline
\end{tabular}

Untuk mengetahui pengaruh dari kelompok larutan uji terhadap daya hambat bermakna atau tidak, maka dilakukan uji lanjut statistika melalui Post Hoc Mann Whithey. Dari nilai $p$ value $(<0,05)$ yang dihasilkan menunjukkan seluruh kelompok larutan uji memiliki pengaruh yang bermakna terhadap diameter zona hambat bakteri (Tabel 4).

Tabel 4. Uji Post HocMann Whitney

\begin{tabular}{clccll}
\hline No & Kelompok Larutan Uji & Nilai p & No & Kelompok larutan uji & Nilai p* \\
\hline 1 & Kontrol negatif vs Ekstrak 20\% & .011 & 8 & Ekstrak 20\% vs kontrol positif & .017 \\
2 & Kontrol negatif vs Ekstrak 40\% & .013 & 9 & Ekstrak 40\% vs Ekstrak 60\% & .027 \\
3 & Kontrol negatif vs Ekstrak 60\% & .013 & 10 & Ekstrak 40\% vs Ekstrak 80\% & .017 \\
4 & Kontrol negatif vs Ekstrak 80\% & .011 & 11 & Ekstrak 40\% vs kontrol positif & .019 \\
5 & Kontrol negatif vs Kontrol positif & .013 & 12 & Ekstrak 60\% vs Ekstrak 80\% & .025 \\
6 & Ekstrak 20\% vs Ekstrak 40\% & .034 & 13 & Ekstrak 60\% vs kontrol positif & .019 \\
7 & Ekstrak 20\% vs Ekstrak 60\% & .017 & 14 & Ekstrak 80\% vs kontrol positif & .017 \\
8 & Ekstrak 20\% vs Ekstrak 80\% & .015 & & & \\
\hline
\end{tabular}




\section{PEMBAHASAN}

Daun senggani yang telah dikumpulkan dilakukan pemisahan dari benda asing, pencucian, pengeringan dan penghalusan. Pemisahan benda asing bertujuan untuk mencegah terjadinya pencemaran pada ekstrak yang dapat mengganggu proses ekstraksi. Pada proses pemisahan benda asing dapat dilakukan secara manual, magnetik atau mekanik. Untuk proses pencucian dilakukan untuk menghilangkan benda asing yang tidak diinginkan melalui aliran air. Selain itu pencucian juga dapat mengurangi jumlah mikroorganisme yang tidak diinginkan pada simplisia. Setelah pencucian dilakukan, selanjutnya simplisia dikeringkan untuk mengurangi kadar air dalam simplisia sehingga dapat menghambat pertumbuhan khamir, kapang atau bakteri. Pengeringan dilakukan secara tidak langsung di bawah sinar matahari untuk mencegah kerusakan senyawa aktif yang tidak tahan terhadap panas.

Daun yang sudah kering dihaluskan dan disaring dengan ayakan untuk mendapatkan ukuran partikel yang homogen. Penghalusan dilakukan untuk menghancurkan bagian-bagian sel pada daun sehingga ukuran simplisia akan menjadi kecil. Hal ini menyebabkan senyawa aktif di dalamnya mudah tersari dalam pelarut. Semakin kecil ukuran partikel dari suatu bahan maka akan memperbesar ukuran luas permukaan bahan sehingga mempercepat zat-zat aktif tersari dalam pelarut. ${ }^{8}$

Serbuk simplisia daun senggani diekstraksi dengan metode maserasi dalam pelarut etanol 96\%.Maserasi merupakan salah satu metode ekstraksi tanpa pemanasan dengan merendam serbuksimplisia dalam pelarut yang sesuai sambil diaduk sesekali pada waktu tertentu.Kelebihan dari metode ini adalah alat dan pengoperasian yang sederhana, biaya yang murah, dan dapat menyari senyawa yang tidak stabil dalam pemanasan.Pelarut yang sering digunakan dalam maserasi adalah metanol, n-heksan, air, dan etanol. Penggunaan etanol 96\% sebagai pelarut karena memiliki beberapa keunggulan seperti tidak beracun, mempunyai daya serap yang baik, dapat menghambat pertumbuhan jamur atau bakteri, dan dapat melarutkan berbagai zat aktif dengan tingkat kepolaran yang berbeda-beda. ${ }^{9}$

Pemilihan pelarut etanol dalam ekstraksi didasarkan pada parameter kelarutan dengan zat aktif yang terkandung dalam ekstrak. Suatu zat yang mudah larut dengan sempurna dalam suatu pelarut apabila zat tersebut memiliki tingkat kepolaran yang mirip dengan pelarutnya. Hal ini sesuai dengan konsep like dissolve like. Etanol merupakan senyawa organik yang bersifat polar dengan gugus hidroksil $(-\mathrm{OH})$ dan nonpolar dengan ikatan antara sesama atom karbon. Oleh sebab itu, etanol dapat menarik senyawa aktif dari suatu ekstrak yang bersifat polar dan nonpolar seperti flavonoid, allkaloid, saponin, tanin dan steroid/triterpenoid.

Dari hasil uji daya hambat ekstrak daun senggani terhadap bakteri Staphylococcus aureus pada Tabel 3 menunjukkankategori zona hambat yang kuat untuk seluruh konsentrasi ekstrak. Kontrol positif berupa kloramfenikol memiliki kategori zona hambat sangat kuat sebesar $27,25 \pm 2,06 \mathrm{~mm}$. Sedangkan NaCMC sebagai kontrol negatif tidak memiliki diameter zona hambat bakteri karena tidakmemiliki senyawa aktif sebagai antibakteri. Diameter zona hambat bakteri ditentukan dengan empat kategori yaitu $<5 \mathrm{~mm}$ tergolong lemah, 5-10 mm tergolong sedang, 10-20 mm tergolong kuat dan $>20$ mm tergolong sangat kuat. ${ }^{10}$

Dengan adanya perbedaan diameter zona hambat tiap-tiap konsentrasi ekstrak terhadap pertumbuhan bakteri Staphylococcus aureus menunjukkan adanya pengaruh kandungan metabolit sekunder pada ekstrak. Konsentrasi ekstrak daun senggani $80 \%$ merupakan konsentrasi ekstrak optimum dalam menghambat pertumbuhan bakteri Staphylococcus aureus karena memiliki zona hambat bakteri tertinggi.Pada Tabel 3 juga menunjukkan diameter zona hambat pada bakteri Staphylococcus aureus semakin besar seiring dengan meningkatnya konsentrasi ekstrak daun senggani.Hal ini memperlihatkan dengan meningkatnya konsentrasi ekstrak daun senggani, semakin banyak zat aktif larut dalam ekstrak daun senggani, maka semakin besar kemampuan metabolit sekunder ekstrak daun senggani berdifusi untuk 
menghambat pertumbuhan bakteri.Kecepatan difusi suatu zat dipengaruhi oleh beberapa faktor, seperti suhu, luas permukaan, dan konsentrasi zat.Semakin besar konsentrasi zat, maka kecepatan difusi semakin tinggi akibatnya makin besar diameter zona hambat bakteri yang terbentuk.

Ekstrak daun senggani mampu menghambatpertumbuhan bakteri Staphylococcus aureus karena diduga adanya peranan senyawa aktif metabolit sekunder seperti flavonoid, alkaloid, saponin, tanin, dan steroid.Senyawa flavonoid dapat menghambat pertumbuhan bakteri dengan menghambat sintesis DNA dan RNA sehingga terjadi kerusakan pada membran sel bakteri. Selain itu, flavonoid juga menghambat metabolisme energi bakteri sehingga dapat mengganggu penyerapan metabolit primer dan sintesis makromolekul bakteri. ${ }^{11}$

Kemampuan saponin dalam menghambat pertumbuhan bakteri adalah dengan meningkatkan aliran cairan pada membran sel sehingga terjadi ketidakstabilan pada membran yang mengakibatkan pecahnya membran sel bakteri. Selain itu, saponin juga dapat mengurangi efisiensi pemanfaatan glukosa dalam mikroorganisme, mengurangi aktivitas enzim, dan menghambat sintesis protein sehingga mengakibatkan terjadinya kematian sel. ${ }^{12}$

Senyawa tannin juga memiliki kemampuan sebagai antibakteri dengan menghambat kerja enzim transkriptase balik dan DNA topoisomerase yang berfungsi sebagai penggandaan sel sehingga bakteri tidak dapat terbentuk dengan jumlah yang banyak. Selain itu, senyawa tannin dapat menghambat keutuhan permeabilitas dinding sel bakteri sehingga bagian terpenting dalam sel seperti protein, nukleotida, dan asam nukleat akan keluar dari sitoplasma yang mengakibatkan terjadinya kematian sel. ${ }^{13}$

Alkaloid yang terdapat pada ekstrak daun senggani sebagai antibakteri dengan caramenghambat enzim menyebabkan inhibisi replikasi DNA dapat menghambat pembelahan pada bakteri. Selain itu, alkaloid juga dapat merusak lapisan dinding sel dengan menggangu terbentuknya jembatan silang komponen penyusun peptidoglikon pada sel bakteri yang mengakibatkan kematian pada sel bakteri. ${ }^{14}$

Pada steroid, mekanisme kerjanya sebagai antibakteridengan mengganggu membran fosfolipid sel yang bersifat permeabel terhadap senyawa-senyawa lipofilik sehingga mengalami penurunan kerja membran dan perubahan bentuk membran sel bakteri. Dari interaksi kereaktifan steroid dengan membran lipid menyebabkan terjadinya kebocoran pada liposom sebagai pengangkut nutrisi bagi bakteri. ${ }^{15}$

Pemilihan kloramfenikol sebagai kontrol positif karenamerupakan antibiotik yang memiliki penghambatan yangluas sehingga dapat digunakan untuk menghambat bakteri Gram-positif dan bakteri Gram-negatif. Antibiotik merupakan zat kimia yang berasal dari pelemahan mikroba untuk mengatasi, mencegah infeksi, dan membunuh bakteri. Mekanisme kerja kloramfenikol melalui struktur $\mathrm{D}(-)$ treo-isomer sebagai antibakteri adalah menghambat pembentukan rantai ikatan peptida sehingga proses sintesis protein menjadi terganggu. Pada toksisitas kadar kloramfenikol yang tinggi dapat bersifat bakterisidal. ${ }^{16}$

Berdasarkan hasiluji statistika Kruskal-Wallispada Tabel 3 diperolehadanyapengaruh antara rata-rata diameter zona hambat pertumbuhan bakteri Staphylococcus aureusdengan kelompok larutan uji $(\mathrm{p}<0,000)$.Untuk mengetahui adanya perbedaan yang bermakna antar kelompok larutan uji, dilakukan uji lanjut post hoc Mann Whitney. Pada Tabel 4, hasil uji post hoc Mann Whitney menunjukkan adanya perbedaan yang bermakna $(\mathrm{p}<0,05)$ untuk setiap dua kelompok larutan uji terhadap diameter zona hambat pertumbuhan bakteri Staphylococcus aureus. Hasil tersebut juga dapat dikatakan bahwa ada perbedaan daya hambat antara keseluruhan konsentrasi ekstrak dengan kloramfeniokol sebagai kontrol positif dan NaCMC sebagai kontrol negatif. Karena adanya perbedaan yang signifikan maka dapat dikatakan adanya pengaruh konsentrasi ekstrak etanol daun senggani terhadap daya hambat pertumbuhan bakteri Staphylococcus aureus. 


\section{SIMPULAN}

Berdasarkan hasil penelitian ini dapat disimpulkan bahwa dengan meningkatnya konsentrasi ekstrak etanol daun senggani maka meningkat pula daya hambat ekstrak terhadap pertumbuhan bakteri Staphylococcus aureus.Hasil statistik menunjukkan adanya pengaruh yang signifikan antara konsentrasi ekstrak daun senggani terhadap daya hambat pertumbuhan bakteri Staphylococcus aureus.

\section{SARAN}

Perlu dilakukan penelitian lanjutan secara khusus mengenai isolasi dan pemurnian dalam menentukan struktur molekul senyawa metabolit sekunder dalam daun senggani yang berperan aktif sebagai antibakteri sehingga dapat dimanfaatkan sebagai bahan baku obat tradisional.

\section{UCAPAN TERIMA KASIH}

Penulis mengucapkan terimakasih kepada Balai Besar Laboratorium Kesehatan (BBLK) Palembang dan Laboratorium Farmasi, Universitas Sriwijaya atas sarana dan prasarana yang disediakan sampai penelitian ini selesai dilakukan. Penulis juga mengucapkan terimakasih kepada para reviewer Jurnal Kesehatan Poltekkes (JKP) Kemenkes RI Pangkalpinang, atas waktu, kesempatan yang diberikan dimuatnya artikel ini dan saran-saranperbaikan demi kesempurnaan artikel ini.

\section{DAFTAR PUSTAKA}

1. Kusmana C, Hikmat A. Keanekaragaman hayati flora di Indonesia. J Pengelolaan Sumberd Alam dan Lingkung. 2015;5(2):187-98.

2. Hapsoh, Hasanah Y. Budidaya Tanaman Obat dan Rempah. Medan: USU Press; 2011.

3. Dalimartha S. Atlas Tumbuhan Obat Indonesia. Jakarta: Trubus Argo Widya; 2000. 68-69 p.

4. Kusumowati ITD, Melannisa R, Prasetyawan A. Daya Antibakteri Ekstrak Etanol Daun Senggani (Melastoma affine D. Don). Biomedika. 2014;6(2):22-5.

5. Purwanto S. Uji Aktivitas Antibakteri Fraksi Aktif Ekstrak Daun Senggani (Melastoma Malabathricum L) terhadap Escherichia Coli. J Keperawatan Sriwij. 2015;2(2):84-92.

6. Barnawi H. Ekstrak daun senggani (Melastoma malabathricum. L) sebagai antibakteri terhadap Streptococcus mutans. UTB. 2017;5(1):31-7.

7. Ondusko DS, Nolt D. Staphylococcus aureus. Pediatr Rev. 2018;39(6):287-98.

8. Kumoro AC. Teknologi Ekstraksi Senyawa Bahan Aktif dari Tanaman Obat. Yogyakarta: Plantaxia; 2015.

9. Marjoni MR. Dasar-dasar fitokimia untuk diploma III farmasi. Jakarta: Trans Info Media; 2016.

10. Susanto DS, Ruga R. Studi kandungan bahan aktif tumbuhan meranti merah (Shorea leprosula Miq) sebagai sumber senyawa antibakteri. Mulawarman Sci. 2012;11(2):181-90.

11. Dzoyem JP, Hamamoto H, Ngameni B, Ngadjui BT, Sekimizu K. Antimicrobial Action Mechanism of Flavonoids from Dorstenia Species. drug Discov Ther. 2013;7(2):66-72.

12. Zhi-hui Y, Xue-zhi D, Li-qiu X, Xiu-qing X, Zhen-ping C, Sha X, et al. Antimicrobial Activity and Mechanism of Total Saponins from Allium chinense. Food Sci. 
2013;34(15):75-80.

13. Mufti N, Bahar E, Arisanti D. Uji Daya Hambat Ekstrak Daun Sawo terhadap Bakteri Escherichia coli secara In Vitro. J Kesehat Andalas. 2017;6(2):289-94.

14. Ernawati E, Sari K. Kandungan senyawa kimia dan aktivitas antibakteri ekstrak kulit buah alpukat (Persea americana P.Mill) terhadap bakteri Vibrio alginolyticus. J Kaji Vet. 2015;3(2):203-11.

15. Sapara TU, Waworuntu O, Juliatri. Efektivitas Antibakteri Ekstrak Daun Pacar Air (Impatiens balsamina L.) Terhadap Pertumbuhan Porphyromonas gingivalis. J Ilm Farm. 2016;5(4):10-7.

16. Dian R, . F, Budiarso F. Uji Resistensi Bakteri Escherichia coli yang Diisolasi dari Plak Gigi terhadap Merkuri dan Antibiotik Kloramfenikol. J e-Biomedik. 2015;3(1):59-63. 